\title{
Feasibility analysis of the implementation of geothermal energy in waters associated for the production of hydrocarbons
}

\author{
Análisis de viabilidad en la implementación de energía geotérmica en \\ aguas asociadas a la producción de hidrocarburos
}

\begin{abstract}
Andrea Bohórquez Araque ${ }^{1}$; Harold Garavito Reyes ${ }^{2}$
Forma de citar: Bohorquez-Araque, A., \& Garavito-Reyes, H. (2021). Feasibility analysis of the implementation of geothermal energy in waters associated for the production of hydrocarbons. Fuentes, el reventón energético, 19(1), 33-43. https://doi.org/10.18273/revfue.v19n1-2021004
\end{abstract}

\begin{abstract}
The water-cut or ratio of water to oil is about $92 \%$ or higher per day in Colombia. In some oil basins like Los Llanos or Putumayo, the water is extracted with relatively high temperatures that are $115^{\circ} \mathrm{C}$, a potential geothermal resource of low-to-medium enthalpy. Usually, this hot water is wasted instead of being used as a resource to generate electricity by the Organic Rankine Cycle (ORC) technology. In this paper, an ORC power plant's technical and economic feasibility analysis is carried out for an oil field with the characteristics mentioned above. The base case for the technical simulation compiles the characteristics and optimal conditions that allow the ORC plant's proper performance. A sensitivity analysis of mass flow and temperature allows the best working fluid and optimum mass flows to obtain the ORC plant's best efficiency. As a result, an ORC module with a geothermal fluid input of $30 \mathrm{~kg} / \mathrm{s}$ and a power output of $1.5 \mathrm{MW}$ is technically feasible. Economically, this module presents an IRR higher than $17 \%$ over 8 years.

The production of efficient, favorable, and sustainable energy through the development of co-generation projects such as ORC geothermal plants can contribute to an oil field's energy demand with positive impacts in a noon carbon tax causation. In addition, this type of project also has social impacts facilitating remote communities to access electricity and clean energy.
\end{abstract}

Keywords: Low-Enthalpy geothermal energy, Organic Rankine Cycle, production water, geothermal energy.

\section{Resumen}

Diariamente en Colombia por cada barril de petróleo se producen 12.02 barriles de agua, este subproducto de las operaciones del petróleo es un recurso geotermal de baja entalpía que se ha desaprovechado, porque con este se puede generar energía eléctrica mediante el uso de un Ciclo Orgánico de Rankine. El objetivo de este proyecto es analizar la viabilidad técnica y económica de implementar un ORC para la generación de electricidad en un caso de estudio que representa las condiciones habituales de un campo petrolero apoyado en el simulador de procesos Aspen Hysys con licencia de la Universidad Industrial de Santander. Se inicia con una revisión literaria que recopila las características y condiciones óptimas que permiten el buen funcionamiento de un ORC, siguiente se simulan los distintos procesos del ORC en Aspen Hysys con el fin de realizar una sensibilidad al flujo másico y a la temperatura que permite establecer el mejor fluido de trabajo y los caudales másicos óptimos para el fluido geotérmico y el fluido de trabajo para finalmente obtener un desarrollo eficiente del ciclo a las características del caso de estudio. Se concluye que es viable técnicamente implementar un modulo ORC para la generación de energía eléctrica en el caso de estudio realizado alcanzando una capacidad de generación para cada pozo de petroleo de $1500 \mathrm{~kW}$ a un flujo másico de fluido geotérmico de $30 \mathrm{~kg} / \mathrm{s}$.

Producir energía eficiente, favorable y sostenible mediante el desarrollo de este proyecto de cogeneración puede contribuir en el ámbito económico en las necesidades energéticas de un campo petrolero, en el ambiental con la no causación al impuesto del carbono y en un ámbito social al desarrollo de las comunidades no conectadas a la red nacional de energía.

Palabras clave: Geotermia de baja Entalpía, Ciclo Orgánico de Rankine, agua de producción, energía geotérmica.

\footnotetext{
${ }^{1}$ Universidad Industrial de Santander, andreabohorquez0209@gmail.com

${ }^{2}$ Universidad Industrial de Santander, yesidgreyes@gmail.com
} 


\section{Introduction}

Electric power generation units using binary cycles constitute the fastest-growing group of geothermal plants due to their capability of using more prevalent low and medium enthalpy resources. Binary ORC usually operates with temperatures ranging from approximately $73{ }^{\circ} \mathrm{C}$ (e.g., in Chena Hot Springs, Alaska) to $200^{\circ} \mathrm{C}$. In these plants, heat is recovered from the geothermal fluid using heat to exchangers to vaporizing a low boiling working fluid (e.g., butane or pentane). This fluid drives a turbine and a power generator. The lower temperature geothermal fluid that leaves the heat exchanger is re-injected back into the reservoir, facilitating sustainable exploitation of resources $^{10}$. In 2012 the share of binary plants was $11 \%$ of the global installed capacity ${ }^{11}$.

An ORC module's working fluids are generally high molecular weight organic fluids with critical thermodynamic properties far below those present in water $^{3}$. These conditions make them feasible to extract energy in a thermodynamic cycle at low temperatures. Therefore, the working fluid choice is crucial during the ORC plant's design stage as it must have optimum thermodynamic properties at the lowest possible temperatures and pressures. Additionally, the working organic fluid should meet several criteria, such as economical, non-toxic, non-flammable, and environmentally friendly fluid $^{4}$. Different authors have cited the use of different organic working fluids for different operational conditions ${ }^{5}$ R123, R227ea, $\mathrm{R} 245 \mathrm{fa}, \mathrm{R} 290$, and n-pentane. Energy balance is carried out to predict operating conditions of the process. Outputs of energy balance are used as input for exergy analysis and components (heat exchanger and turbine. For example, in the literature it is found simulations of ORC modules associated with geothermal fluid temperatures below $200{ }^{\circ} \mathrm{C}$ that use different working fluids as R227ea. Also R245fa are found more efficient for temperature range geothermal fluid of 80-160 and $160-200{ }^{\circ} \mathrm{C}^{6}$. This article selected three study fluids: Propane, n-Butane, and R134a as working fluids for analysis; based on a rigorous literature review ${ }^{7-9}$ about the optimal fluids for ORC technology in the conditions presented here.

\section{Theoretical Background}

An organic Rankine cycle (ORC) is a module that consists of 4 components: a heat exchanger, a turbine, a condenser, and a pump. The objective of this module is to take advantage of the thermal energy coming from a geothermal fluid to generate electricity using a secondary fluid, like propane, that has a boiling point lower than that the water.

Figure 1 shows the process inside the ORC module with propane that are constituted by these steps: 1) The propane is compressed in the feed pump, 2) heated, 3 ) evaporated in the heat exchanger and 4) expanded in the turbine. In the last step, the remaining heat is removed in the condenser. In an ideal case, the changes of state would be as follows':

1-2 isentropic compression, cycle work supply,

2-3 isobaric heat supply (heat exchanger),

3-4 isentropic expansion when work is carried out outside the cycle,

4-1 isobaric heat removal (condenser).

Depending on the pressure at which the heat is supplied, the process could be subcritical, and the working fluid can evaporate when flowing through the biphasic region (black line, Figure 1b) or supercritical (dotted line, Figure 1b). The location of the critical point $(\mathrm{CP})$ would depend on the working fluid chosen.

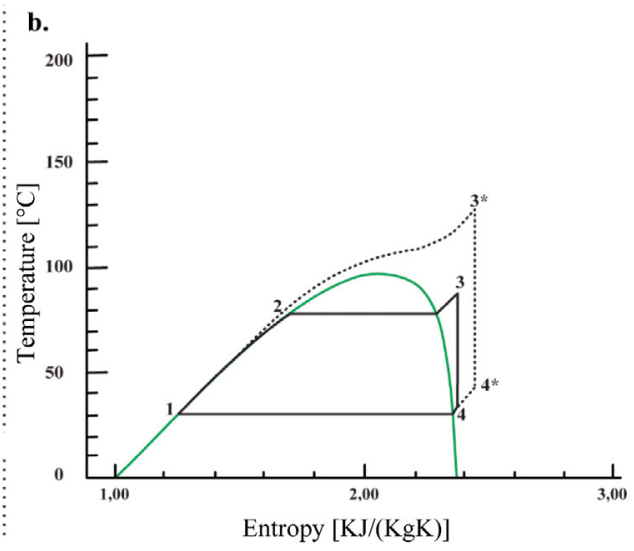

Figure 1a. Flowchart of an ORCmodule; Figure 1b. Temperature vs Entropy Diagram for Propane in an ORC ${ }^{9}$. 
Each component's specific energy contribution can be calculated from the differences in enthalpy (h1, h2, h3, h4) in the individual status points.

Work supplied to the feed pump:

$$
\dot{W}_{\text {pump }}=h 2-h 1
$$

Heat supplied to the heat exchanger:

$$
\dot{Q}_{i n}=h 3-h 2
$$

Turbine specific work:

$$
\dot{W}_{\text {Turbine }}=h 3-h 4
$$

The heat removed in the condenser:

$$
\dot{Q}_{\text {out }}=h 4-h 1
$$

This is why the thermal efficiency of the cycle can be calculated:

$$
n_{\text {thermal }}=\frac{\left|\dot{Q}_{\text {in }}\right|-\left|\dot{Q}_{\text {out }}\right|}{\left|\dot{Q}_{\text {in }}\right|}=\frac{\left|\dot{W}_{\text {turbine }}\right|-\left|\dot{W}_{\text {pump }}\right|}{\left|\dot{Q}_{\text {in }}\right|}=\frac{(h 3-h 4)-(h 2-h 1)}{h 3-h 2}
$$

The process described above is an ideal case, which in reality is affected by losses. Pressure losses in the pipes, heat exchanger, and condenser cannot be avoided. Besides, there are losses during compression in the pump and expansion in the turbine. These losses result in an increase in the entropy during the compression and expansion. This can be described with the isentropic pump and turbine efficiency:

$$
n_{\text {pump }}=\frac{h 2^{\text {losses }}-h 1}{h 2-h 1}
$$

$$
n_{\text {turbine }}=\frac{h 3-h 4}{h 3-h 4^{\text {losses }}}
$$

The geothermal fluid provides the heat source for the process, the heat is extracted in the heat exchanger, and this is a sensitive heat source as the temperature of the hot water during heat dissipation changes. This is why the so-called triangle cycle is used as an ideal comparison process instead of the Carnot cycle to calculate an efficiency with a more realistic upper limit. The efficiency of this process can be calculated from the upper and lower process temperature (Tmax y Tmin) as well as Carnot's efficiency ${ }^{12}$.

$$
n_{c}=1-\frac{T \min }{\operatorname{Tmax}}
$$

$$
n_{\text {triangular }}=\frac{\operatorname{Tmax}-\operatorname{Tmin}}{\operatorname{Tmax}+\operatorname{Tmin}}
$$

Working fluid. The choice of working fluid has significant implications on the efficiency of the ORC. While there are many articles available for working fluids, there are also many limitations in the selection related to the thermodynamic properties of the fluids and health, safety, and environmental considerations. The selection of the working fluid depends on its thermodynamic properties. The working fluid must meet the following criteria, among others ${ }^{13}$ : Low critical pressure and temperature (compared to water), low specific volume, high thermal conductivity, non-corrosive, non-toxic, low boiling point, low evaporation enthalpy, Also, low ozone depletion potential (ODP) and a low Global Warming Potential (GWP) are essential requirements for the suitability of the working fluid ${ }^{12}$. Table 1 shows the environmental and health properties of the primary candidate fluids.

Table 1. Environmental and health properties of working fluids.

\begin{tabular}{cccccc}
\hline Fluid & Formulate & Toxicity & Inflammability & ODP & GWP \\
\hline R-12 & CC12F2 & Non-toxic & No Inflammable & 1.0 & 4500 \\
R-114 & C2Cl2F4 & Non-toxic & No Inflammable & 0.7 & 5850 \\
Propane & C3H8 & Low & Very High & 0 & 3 \\
i-Butane & i-C4H10 & Low & Very High & 0 & 3 \\
n-Butane & C4H10 & Low & Very High & 0 & 3 \\
i-Pentane & i-C5H12 & Low & Very High & 0 & 3 \\
n-Pentane & C5H12 & Low & Very High & 0 & 3 \\
R-32 & CH2F2 & Low & Low & 0 & 675 \\
R-134a & C2H2F4 & Very Low & No Inflammable & 0 & 1300 \\
R-245fa & C3H3F5 & Very Low & No Inflammable & 0 & 1020 \\
Carbon Dioxide & CO2 & Non-toxic & No Inflammable & 0 & 0 \\
Ammonia & NH3 & toxic & Low & 0 & 0 \\
Water & H2O & Non-toxic & No Inflammable & 0 & - \\
\hline
\end{tabular}


Thermodynamic properties. Table 2 lists some candidate fluids and their relevant thermodynamic properties; pure water is included for comparison ${ }^{14}$. In Figure 2, it can observe the biphasic regions of some organic fluids and water. All candidate fluids have much lower critical temperatures and pressures than water. Besides, since critical pressures are reasonably low, it is feasible to consider supercritical cycles for hydrocarbons ${ }^{12}$.

Table 2. Thermodynamic properties of some ORC candidate working fluids.

\begin{tabular}{cccccccc}
\hline Fluid & formulate & $\begin{array}{c}\text { Tc } \\
{ }^{\circ} \mathbf{C}\end{array}$ & $\begin{array}{c}\text { Tc } \\
{ }^{\circ} \mathbf{F}\end{array}$ & $\begin{array}{c}\text { Pc } \\
\text { MPa }\end{array}$ & $\begin{array}{c}\text { Pc } \\
\text { PSI }\end{array}$ & $\begin{array}{c}\text { Ps @ } \\
\mathbf{3 0 0} \mathbf{K} \\
\mathbf{M P a}\end{array}$ & $\begin{array}{c}\text { Ps @ } \\
\mathbf{4 0 0} \mathbf{K} \\
\mathbf{M P a}\end{array}$ \\
\hline Propane & $\mathrm{C}_{3} \mathrm{H}_{8}$ & 96.95 & 206.5 & 4.236 & 614.4 & 0.9935 & NA \\
i- Butane & $i-\mathrm{C}_{4} \mathrm{H}_{10}$ & 135.92 & 276.7 & 3.685 & 534.4 & 0.3727 & 3.204 \\
n- Butane & $\mathrm{C}_{4} \mathrm{H}_{10}$ & 150.8 & 303.4 & 3.718 & 539.2 & 0.2559 & 1.238 \\
i- Pentane & $i-\mathrm{C}_{5} \mathrm{H}_{12}$ & 187.8 & 370.1 & 3.409 & 494.4 & 0.09759 & 1.238 \\
n- Pentane & $\mathrm{C}_{5} \mathrm{H}_{12}$ & 193.9 & 380.9 & 3.240 & 469.9 & 0.07376 & 1.036 \\
Ammonia & $\mathrm{NH}_{3}$ & 133.65 & 272.57 & 11.627 & 1686.3 & 1.061 & 10.3 \\
Water & $\mathrm{H}_{2} \mathrm{O}$ & 374.14 & 705.45 & 22.089 & 3203.6 & 0.003536 & 0.24559 \\
\hline
\end{tabular}
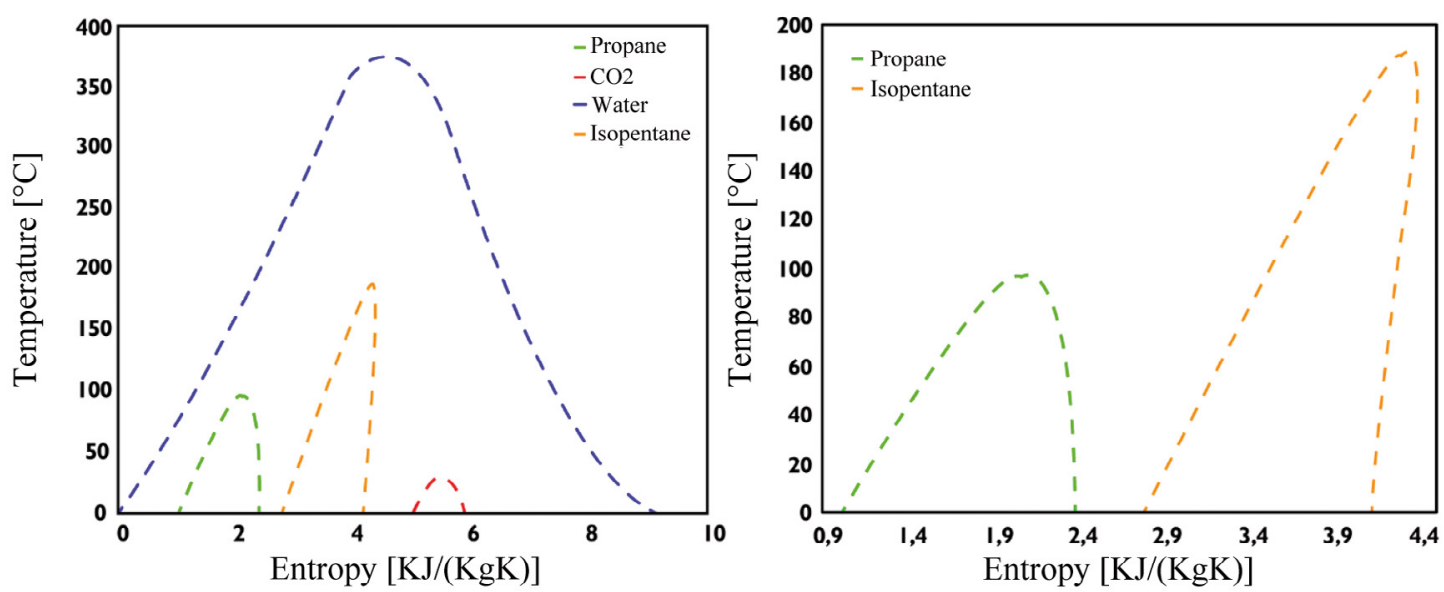

Figure 2. Biphasic regions of some organic fluids and Water'.

Turbine. The thermodynamic analysis of the cycle is relatively straightforward starting with the binary turbine. The components of the system flow diagram are included in Figure 1 for an easy reading with the components cited.

With the usual assumptions of negligible potential and kinetic energy terms along with the stable adiabatic operation, the power is from:

$$
\dot{W}_{\text {Turbine }}=\dot{m}_{f t}(h 3-h 4)=\dot{m}_{f t} \mathrm{n}_{t}\left(h 3-h 4^{\text {losses }}\right)
$$

Where is the isentropic Turbine efficiency, which is a known quantity and is a mass flow of working fluid. For a given working fluid, the thermodynamic properties can be easily found from tables or correlations for any design parameter you choose. The desired turbine power output then determines the required working fluid mass flow rate ${ }^{12}$.
Heat exchanger. The heat exchanger analysis where the geothermal fluid transfers some of its thermal energy to the working fluid is another direct application of thermodynamics and mass conservation principles. We assume that the heat exchangers are well insulated so that all heat transfer occurs between the geothermal fluid and the working fluid. According to our general assumptions, we also assume that the flow is stable and that the differences in entering and leaving potential energy and kinetic energy are negligible ${ }^{12}$.

The heat input can then be calculated using an energy balance on the heat exchanger:

$\dot{Q}_{\text {geo }}=\dot{m}_{\text {geo }} * c_{p, \text { geo }} *\left(T_{\text {geo, in }}-T_{\text {geo,out }}\right)=\dot{m}_{O R C} *(h 3-h 2)=\dot{Q}_{\text {in }}$

The left side of the equation is the heat extracted from the geothermal fluid. This can be calculated from the temperature difference of the geothermal fluid between 
the heat exchanger's input and output and the specific average isobaric heat capacity " $\mathrm{Cp}$ " of the geothermal fluid. This heat leads to an increase in enthalpy and, therefore, to the organic fluid's evaporation on the secondary side. That means that the heat extracted from the geothermal fluid is equal to the heat supplied to the heat exchanger

The finite area of heat exchange leads to temperature differences between the two fluids at all points of the heat exchanger. Therefore, an important design parameter for the heat exchanger is the minimum temperature difference (MTD) between the two fluids. The point where this occurs MTD is the "pinch point," this point depends on two factors:

1. The pressure and temperature of the organic fluid leaving the heat exchanger.

2. The temperature of the geothermal fluid at the entry point.

Environmental benefits. The reduced environmental impact associated with using geothermal resources compared to the impact caused by most energy sources promotes the basis for their development in all types of systems. As in table 3. Average emission of polluting gases ${ }^{15}$. shows the average emission of the leading gases generated when producing electricity by the most common energy sources, including binary geothermal energy.

Table 3. Average emission of polluting gases ${ }^{15}$.

\begin{tabular}{lccc}
\hline $\begin{array}{c}\text { Type of } \\
\text { Energy }\end{array}$ & $\begin{array}{c}\text { Sulfur Dioxide } \\
\text { (LB/MWh) }\end{array}$ & $\begin{array}{c}\text { Carbon Dioxide } \\
\text { (LB/MWh) }\end{array}$ & $\begin{array}{c}\text { Nitrogen Oxide } \\
\text { (LB/MWh) }\end{array}$ \\
\hline Coal & 10,39 & 2191 & 4,31 \\
Oil & 12 & 1672 & 4 \\
Natural Gas & 0,22 & 1212 & 2,96 \\
Flash & 0,35 & 60 & 0 \\
Geothermal & & 0 & 0 \\
$\begin{array}{l}\text { Binary } \\
\text { Geothermal }\end{array}$ & 0 & & \\
\hline
\end{tabular}

There are no emissions from combustion processes in power plants using geothermal resources, so their electricity is environmentally friendly, renewable, and sustainable. Emissions associated with binary cycle geothermal power plants are close to zero, while those from flash plants using high-temperature steam vary widely depending on the resource ${ }^{15}$.

Apart from the emission of polluting gases, other positive aspects of geothermal energy from oil wells can also be highlighted: (a) No liquid discharges are generated from the generation process as the fluids are re-injected, (b) no new land areas are required since the development of this energy will be done in the area of oil activity, (c) there is practically no possibility of contamination of the surface installations or the surrounding area by the discharge of solids from the geothermal fluid itself $f^{15}$. Noise from geothermal operations is typical of many activities during the drilling, stimulation, and well-testing phases ${ }^{16}$.

\section{Simulation and Results}

This section contains the selection of a case study based on the conditions set out in the previous section: The Rankine Organic Cycle (ORC) scheme used, the simulation and sensitivity of the parameters affecting power generation in the turbine to establish the technical feasibility of implementing low-enthalpy geothermal energy in an oil field.

Case Study Selection. The existence of geothermal potential is the first aspect to be evaluated in the development of low enthalpy projects. Therefore for the location of the case study, the estimation of the Colombian geothermal gradients supplied by the ANH and INGEOMINAS is used from temperature measurements recorded in about 4600 wells drilled by the oil industry (Alfaro, Alvarado, Quintero, Vargas, \& Briceño, 2009) where it is determined that one of the greatest gradients is in the eastern plains basin. Therefore the location of the EIP Field that will be the name of the case of study is established in this zone.

The area of development of the EIP Field has identified a temperature range of $70{ }^{\circ} \mathrm{C}$ to $120{ }^{\circ} \mathrm{C}$ that is set for surface production water based on:

1. This range corresponds to the geothermal fluid temperature used in the generation of electricity with low enthalpy geothermal.

2. There is an average geothermal gradient of $31{ }^{\circ} \mathrm{C} /$ $\mathrm{Km}$ in the eastern plains basin.

3. $70{ }^{\circ} \mathrm{C}$ is the minimum temperature at which a project of this type has been successfully developed in the world (in Chena Hotspring). Besides is the minimum temperature at which companies supplying this equipment can guarantee energy generation.

The EIP field is a black oil field with an active aquifer and API gravity oil of 32, and this field has 3 wells drilled and in production. Table 9. Shows this primary production data. 
Table 4. Production data EIP field.

\begin{tabular}{rcccccc}
\hline Well & Fluid rate (bfpd) & Oil rate (bfpd) & \%BSW & GOR (scf/bopd) & Temperature $\left({ }^{\circ} \mathbf{C}\right)$ & WHP $(\mathbf{p s i})$ \\
\hline EIP -1 & 28482.58 & 1252.58 & 95.4 & 625 & 80 & 220 \\
EIP -2 & 22193.82 & 413.82 & 98.1 & 106 & 95 & 90 \\
EIP -3 & 16748.5 & 408.5 & 97.5 & 342 & 120 & 70 \\
\hline
\end{tabular}

The following working fluids are selected for ORC development: propane, n-Butane, and R134a, as they are commonly used fluids due to their low boiling point and high steam pressure at low temperatures. Water steam is also easily accessible and complies with environmental regulations.

Organic Rankine Cycle in Aspen Hysys. A simple ORC consists of four pieces of equipment, a heat exchanger where energy is transferred between the production water and the working fluid to bring this fluid to a temperature above the saturated steam line, a turbine that transforms the internal energy of the steam into mechanical energy, a condenser and a pump that recirculates the cycle. Figure 3 shows the ORC illustration implemented in the EIP field and simulated in ASPEN HYSYS v8.8 with a Universidad Industrial de Santander license.

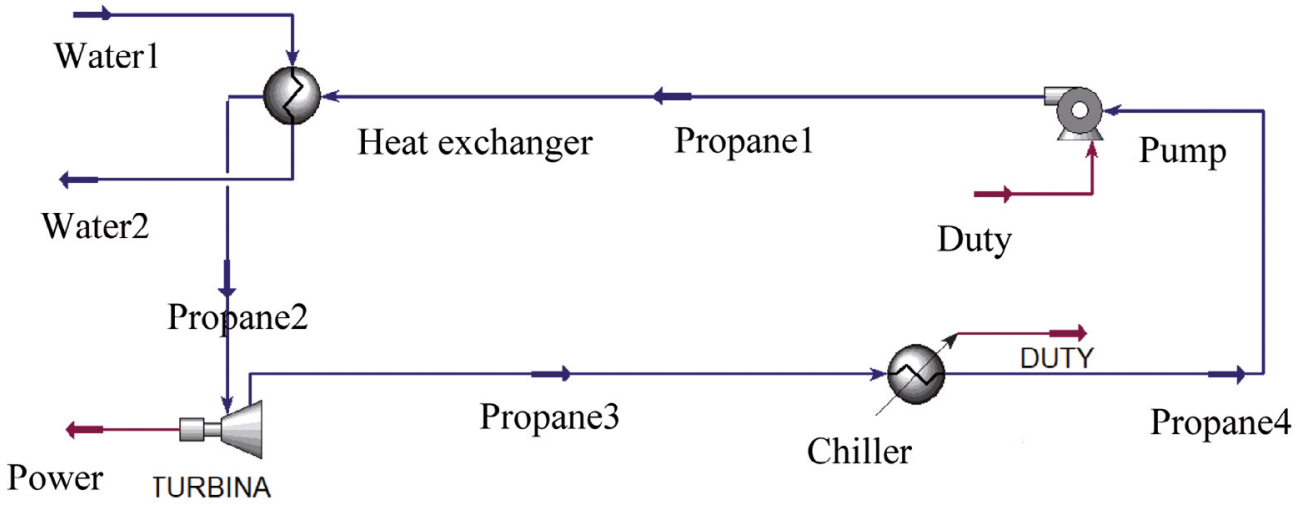

Figure 3. Propane ORC scheme implemented in the EIP field.

Mass flow sensitivity. A sensitivity analysis was carried out on the variation in the geothermal fluid's mass flows and the three working fluids at the heat exchanger entrance to see how these changes affect the power generated in the turbine. In addition, the temperatures of $70{ }^{\circ} \mathrm{C}$ and $120{ }^{\circ} \mathrm{C}$ in the geothermal fluid were used to evaluate further the working fluid's efficiency at these two extremes.

The following figures show the power as a function of the mass flow of the geothermal fluid and the working fluid. The dashed lines represent a range in which it is not possible to operate the cycle since the heat exchange between the two fluids is not sufficient for the working fluid to reach its saturated steam phase and perform work on the turbine.

The choice of mass flow for propane is limited to geothermal fluid flow, allowing a complete phase change in the organic fluid. For example, the mass flow of $30 \mathrm{~kg} / \mathrm{s}$ propane is the most efficient; however, it has a reduced operating range from $40 \mathrm{~kg} / \mathrm{s}$ to $60 \mathrm{~kg} / \mathrm{s}$ geothermal fluid flow to $70{ }^{\circ} \mathrm{C}$ as seen in Figure 4 ; to cover a broader category is recommended to use a mass flow of $25 \mathrm{~kg} / \mathrm{s}$ of propane.

The increase in the geothermal fluid's mass flow at a constant temperature produces a slight increase in heat exchange and increased power.

In Figure 5, the sensitivity graph at $70{ }^{\circ} \mathrm{C}$ is not included because the enthalpy gain needed to raise the butane temperature above $36.87^{\circ} \mathrm{C}$ (saturation temperature at 50 psia) is not sufficient. It can be seen that the most potent butane mass flow is $30 \mathrm{~kg} / \mathrm{s}$ when the geothermal fluid mass flow is over $35 \mathrm{~kg} / \mathrm{s}$ for a constant temperature of $120^{\circ} \mathrm{C}$. 


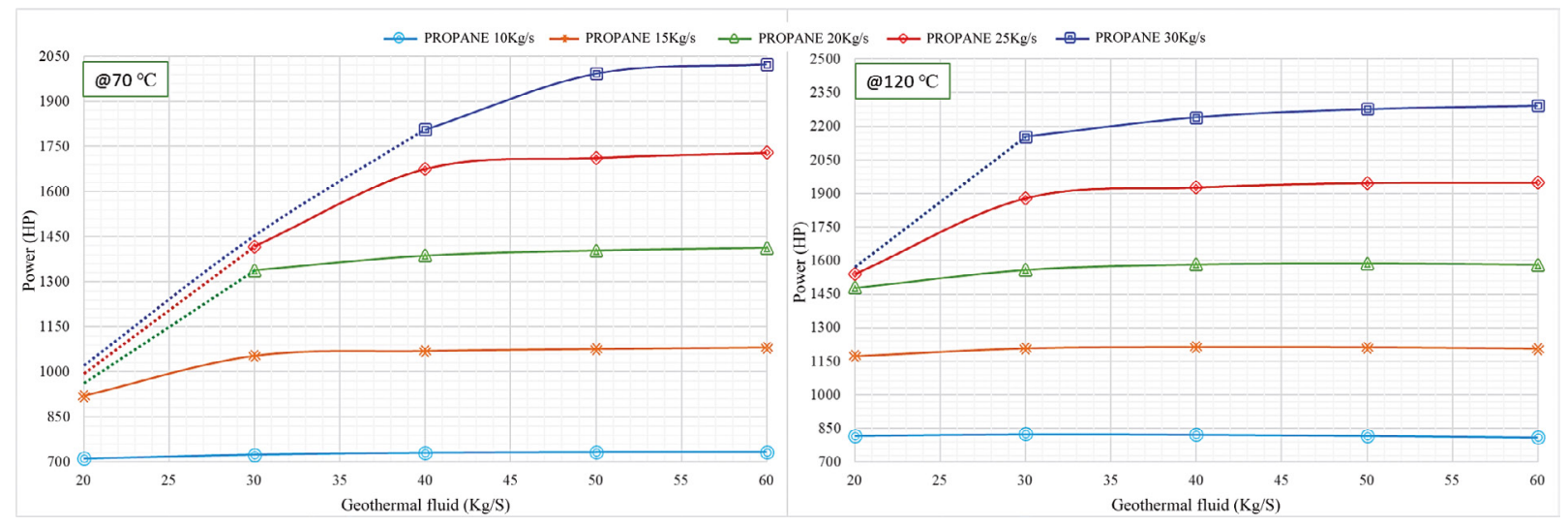

Figure 4. Sensitivity to propane mass flow at a temperature of $70{ }^{\circ} \mathrm{C}$ and $120^{\circ} \mathrm{C}$ of geothermal fluid.

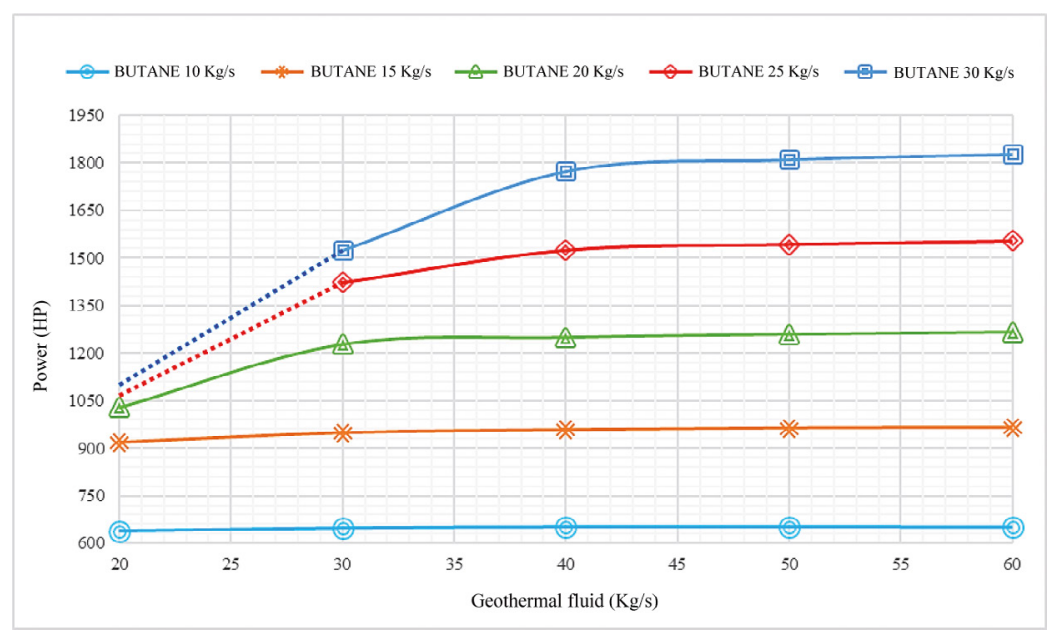

Figure 5. Sensitivity to n-butane mass flow at a temperature of $120^{\circ} \mathrm{C}$.

In Figure 6, the R134a refrigerant works in the range of $20-60 \mathrm{~kg} / \mathrm{s}$ of geothermal fluid. In this case, it can be used in projects where the production water flow is low.
The power generated increases with increasing R134A mass flow, but the change in power is indifferent to the increase in geothermal fluid mass flow.

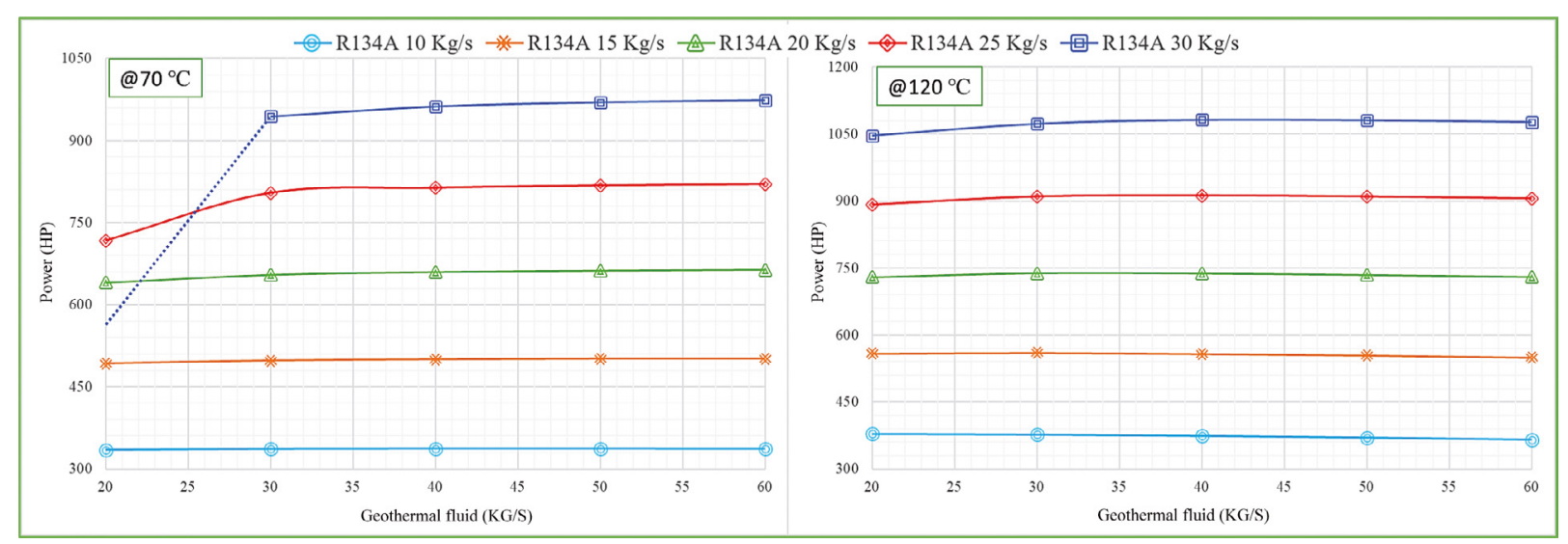

Figure 6. Mass flow sensitivity of R134a at a temperature of $70{ }^{\circ} \mathrm{C}$ and $120^{\circ} \mathrm{C}$ of geothermal fluid. 
Geothermal fluid temperature sensitivity. The temperature is the critical parameter to evaluate since it is the fundamental property of the geothermal resource and indirectly speaks of the amount of enthalpy that can yield to the cycle. For example, in Figure 7, Figure 8 and Figure 9 the behaviour of the power generated in the turbine is observed when the temperature of the geothermal fluid increases from $70{ }^{\circ} \mathrm{C}$ to $120{ }^{\circ} \mathrm{C}$, the reading is made at different geothermal fluid flows.
The analysis was performed for each working fluid at a standard mass flow rate of $25 \mathrm{~kg} / \mathrm{s}$.

The propane behavior is described in Figure 7, as the geothermal fluid's temperature increases, the turbine's power increases significantly. However, only the increase in mass flow from $30 \mathrm{~kg} / \mathrm{s}$ to $40 \mathrm{~kg} / \mathrm{s}$ of geothermal fluid generates a substantial increase in power.

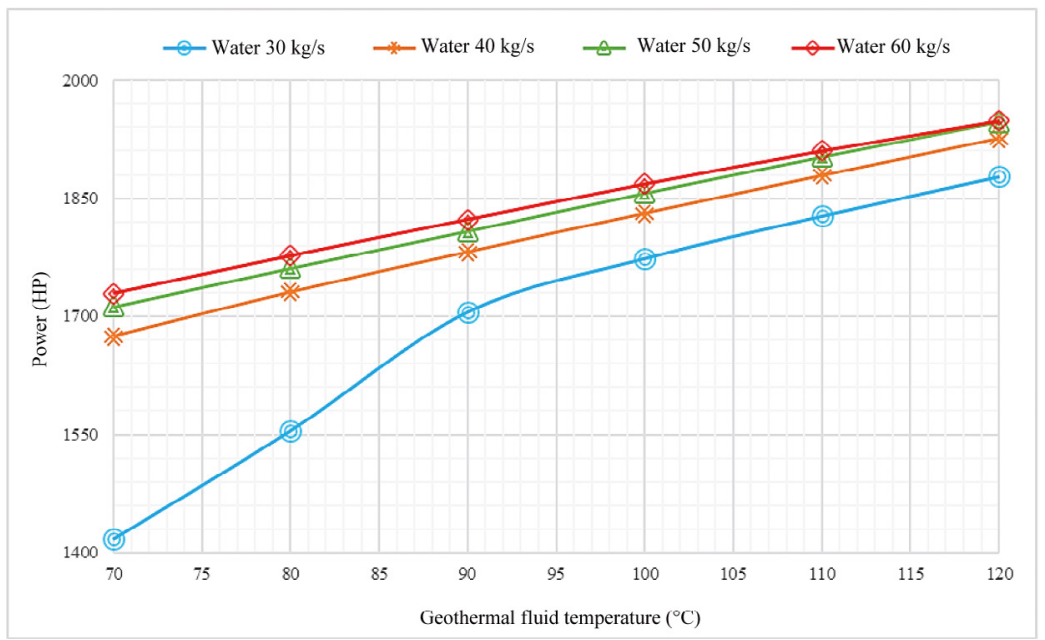

Figure 7. Power generated in the turbine vs temperature geothermal fluid for different mass flow values of water a one constant flow rate of working fluid (Propane) of $25 \mathrm{~kg} / \mathrm{s}$.

Butane is a fluid with limitations regarding the temperature and quantity of the geothermal resource flow. In Figure 9, the dotted lines represent a range where the enthalpy needed to bring the butane above its saturated vapor phase is not sufficient. It was necessary to work with a mass flow above $40 \mathrm{~kg} / \mathrm{s}$ since a lower mass flow of geothermal fluid is inefficient in the heat transfer necessary for the cycle to work when the working fluid is n-butane. Also, it should be noted that the $60 \mathrm{~kg} / \mathrm{s}$ flow is the only one that operates in the temperature range $70{ }^{\circ} \mathrm{C}$ to $120{ }^{\circ} \mathrm{C}$ and produces the highest amount of power.

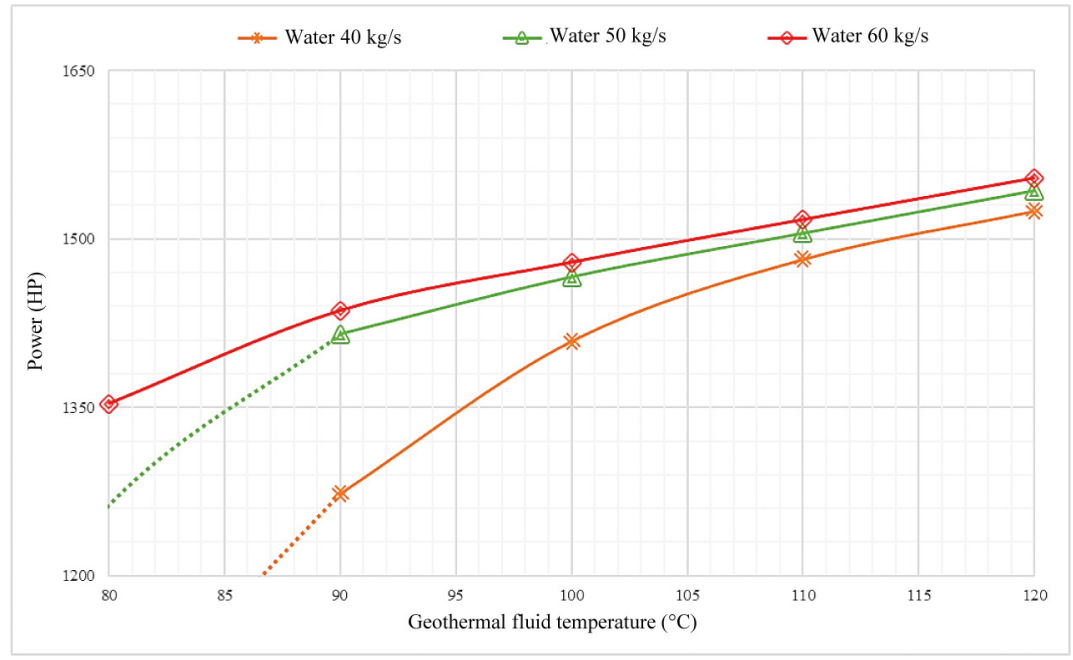

Figure 8. Power generated in the turbine vs temperature geothermal fluid for different mass flow values of water a one constant flow rate of working fluid (Butane) of $25 \mathrm{~kg} / \mathrm{s}$. 
R134a exhibits excellent performance in the conditions evaluated, as seen in Figure 9. The power generated by the turbine is only slightly affected by changes in flow, whereas the increase in the geothermal fluid temperature has a favorable effect on power generation. Furthermore, by increasing the difference between the proportion of the water mass flow and the coolant, the heat transfer system loses efficiency and the power generated in the turbine, as shown in the line representing $60 \mathrm{~kg} / \mathrm{s}$ and $50 \mathrm{~kg} / \mathrm{s}$.

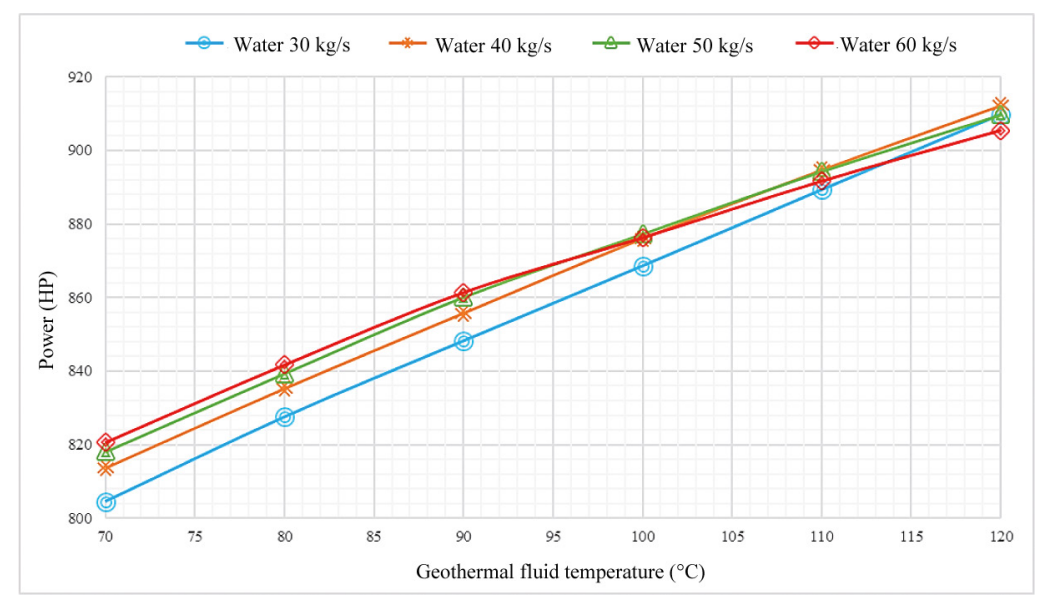

Figure 9. Power generated in the turbine vs temperature geothermal fluid for different mass flow values of water a one constant flow rate of working fluid (R134a) of $25 \mathrm{~kg} / \mathrm{s}$.

Development of ORC in the EIP field. For the three producing wells in this field, the following methodology was used to deliver the maximum power that each well can generate:

1. Estimation of well potential: Used the Figure 7, Figure 8 y Figure 9 where the conditional power in the turbine is determined at the temperature and mass flow of the geothermal fluid at a condition of $25 \mathrm{~kg} / \mathrm{s}$ for the working fluid, in this way, can be estimated a generation potential for each well.

2. Determine the optimal organic fluid flow: Figure 4, Figure 5, and Figure 6 determine the organic fluid mass flow that generates the most power and the most efficient.

3. Correct the amount of power generated in the turbine: With the fluid selection and the optimal working fluid flow in the previous point, the real power produced in the turbine by each well is determined.

Table 5 shows the results obtained by applying the methodology proposed for the implementation and technical optimization of the ORC module in the wells understudy in the EIP field
Table 5. Development of ORC in the EIP field wells.

\begin{tabular}{|c|c|c|c|}
\hline Well & EIP-1 & EIP-2 & EIP-3 \\
\hline Geothermal fluid temperature $\left({ }^{\circ} \mathrm{C}\right)$ & 80 & 95 & 120 \\
\hline $\begin{array}{l}\text { The mass flow rate of the geothermal } \\
\text { fluid }(\mathrm{Kg} / \mathrm{s})\end{array}$ & 50 & 40 & 30 \\
\hline Power approx. (Hp) & 1761 & 1807 & 1878 \\
\hline Working fluid & Propane & Propane & Propane \\
\hline $\begin{array}{l}\text { The mass flow rate of the working } \\
\text { fluid }(\mathrm{Kg} / \mathrm{s})\end{array}$ & 30 & 30 & 25 \\
\hline Power (Hp) & 2050 & 2097 & 1878 \\
\hline
\end{tabular}

\section{Discussion of Results}

The analysis was made to the EIP field where a case of study was made to resemble a real oil field's properties; This field is located in the eastern plains basin from Colombia with high geothermal potential. The well's objects of this study were EIP-1, EIP-2, and EIP-3.

The sensitivity analyses performed on the mass flow in Figure 4, Figure 5, Figure 6 teach us that it is necessary to guarantee the approximate 1:2 proportionality of working fluid mass flow with the geothermal fluid mass flow to ensure the optimal operation ORC module. In other words, an increase in the geothermal fluid mass flow allows an increase in the working fluid mass flow, which increases the power generated in the module. 
Figure 7, Figure 8, and Figure 9 demonstrated that the temperature of the geothermal fluid is the determining parameter in operation and efficiency of the cycle and that it contributes significantly to increasing the power generated in the turbine; having geothermal resources in the range of $95{ }^{\circ} \mathrm{C}$ to $120^{\circ} \mathrm{C}$ contributed to the technical and economic feasibility of the project.

The 3 organic fluids studied result from the bibliographic compilation where propane turns out to be the most efficient fluid as it generates an approximate power range in the turbine of $711 \mathrm{Hp}$ to $2292 \mathrm{Hp}$ according to the conditions established for the simulation. While butane is the fluid with the most significant limitation for its use and R134a shows excellent stability and performance despite being the fluid that generates less power.

Traces of hydrocarbons and contaminants present in produced water were not considered for the analysis; however, these parameters can decrease the project's life and efficiency. It is recommended that these parameters be included in a future investigation.

This type of project can be considered an improvement of the initial conditions established if the heat generated by other equipment in the oil location is managed to increase the enthalpy of the production water before it enters the heat exchanger.

The project's implementation was carried out in wells in the production stage; therefore, the exploration, drilling, and development of the geothermal field are pre-existing stages of detailed information about their characteristics. Therefore it is not necessary to incur new studies in this area when evaluating the technical feasibility.

\section{Conclusions}

The Colombian oil industry has an important geothermal resource in its production waters which can be successfully and profitably exploited, given that the characteristics of the EIP field are not indifferent to those of many Colombian fields.

The EIP field located in the Eastern Plains Basin has low enthalpy geothermal resources with favorable temperatures between $70^{\circ} \mathrm{C}-120^{\circ} \mathrm{C}$ and reasonable flows rates between $30 \mathrm{l} / \mathrm{s}-50 \mathrm{l} / \mathrm{s}$, which are excellent electricity generation conditions for the use of Organic Rankine Cycles.
Temperature is the most critical factor in assessing the technical feasibility of a low-enthalpy geothermal energy project; however, other factors in the ORC configuration can enhance cycle efficiencies, such as the proper choice of working fluid and heat exchanger and turbine design parameters.

The development of this technology to take advantage of the geothermal energy present in the production water associated with the hydrocarbon wells would represent in Colombia an important diversification of the energy matrix and energy suppliers, something that is in line with compliance with the Sustainable Development Goals, especially goal 7: affordable and clean energy.

\section{Nomenclature}

\begin{tabular}{|c|c|}
\hline$c_{p, g e o}$ & Geothermal fluid heat capacity \\
\hline GWP & Global Warming Potential \\
\hline$h$ & Entalpy \\
\hline LMTD & Logarithmic mean temperature difference \\
\hline$\dot{m}_{f t}$ & Mass Flow of Working Fluid \\
\hline$\dot{m}_{g e o}$ & Geothermal Fluid Mass Flow \\
\hline$\dot{m}_{O R C}$ & ORC Input Mass Flow \\
\hline MTD & $\begin{array}{l}\text { Minimum temperature difference between } \\
\text { the two fluids }\end{array}$ \\
\hline$n_{\text {pump }}$ & Pump efficiency \\
\hline$n_{c}$ & Carnot Efficiency \\
\hline$n_{\text {turbine }} ; n_{t}$ & Turbine efficiency \\
\hline$n_{\text {thermal }}$ & Cycle thermal efficiency \\
\hline$n_{\text {triangular }}$ & Triangular Efficiency \\
\hline ODP & Ozone Depletion Potential \\
\hline ORC & Organic Rankine Cycle \\
\hline Pc & Critical Pressure \\
\hline Ps & aturation Pressure \\
\hline$\dot{Q}_{\text {in }}$ & Heat supplied to the heat exchanger \\
\hline$\dot{Q}_{g e o}$ & $\begin{array}{l}\text { The heat extracted from the geothermal } \\
\text { fluid }\end{array}$ \\
\hline$\dot{Q}_{\text {out }}$ & The heat removed in the condenser \\
\hline Tc & Critical temperature \\
\hline $\operatorname{Tmax}$ & Maximum temperature \\
\hline $\operatorname{Tmin}$ & Minimum temperature \\
\hline$T_{g e o}$ & Geothermal fluid temperature \\
\hline$\dot{W}_{\text {pump }}$ & Work supplied to the feed pump \\
\hline & Turbine specific work \\
\hline
\end{tabular}




\section{References}

ANH, Agencia Nacional de Hidrocarburos, Colombia. Available at: http://www.anh.gov.co. (Accessed: 21st August 2018).

Bertani, R. "Geothermal power generation in the world 2005-2010 update report". Geothermics 41, 1-29 (2012).

Caldiño-Herrera, U., García, J. C., Sierra-Espinosa, F. Z. \& Dávalos, J. "Diseño termodinámico de un ciclo Rankine orgánico para el aprovechamiento energético de aguas termales". 6 (2017).

DiPippo, R. "Binary Cycle Power Plants". in Geothermal Power Plants 193-239 (Elsevier, 2016). doi: 10.1016/B978-0-08-100879-9.00008-2.

DiPippo, R. "Geothermal energy Electricity generation, and environmental impact". Energy Policy 19, 798807 (1991).

Gu, Z. \& Sato, H. "Performance of supercritical cycles for geothermal binary design". Energy Convers. Manag. 43, 961-971 (2002).

Heberle, F. \& Brüggemann, D. "Exergy based fluid selection for a geothermal Organic Rankine Cycle for combined heat and power generation". Appl. Therm. Eng. 30, 1326-1332 (2010).

International Energy Agency. Technology Roadmap: Geothermal Heat and Power. (OECD Publishing, 2011). doi: $10.1787 / 9789264118485$-en.

Lakew, A. A. \& Bolland, O. "Working fluids for lowtemperature heat source". Appl. Therm. Eng. 30, 1262-1268 (2010).

Lee, K. C. Classification of Geothermal Resources - An engineering approach. (Geothermal Institute, The University of Auckland, Auckland, NZ, 1996).

Maizza, V. \& Maizza, A. "Working fluids in non-steady flows for waste energy recovery systems". Appl. Therm. Eng. 16, 579-590 (1996).

Reynolds, W. C. Thermodynamic properties in SI: graphs, tables, and computational equations for forty substances. (Stanford, CA: Dept. of Mechanical Engineering, Stanford University, 1979).

Sanyal, S. K., Butler, S. J. \& Drive, B. "Geothermal Power Capacity from Petroleum Wells - Some Case Histories of Assessment".

Shengjun, Z., Huaixin, W. \& Tao, G. "Performance comparison and parametric optimization of subcritical Organic Rankine Cycle (ORC) and transcritical power cycle system for lowtemperature geothermal power generation". Appl. Energy 88, 2740-2754 (2011).
The future of geothermal energy: impact of enhanced geothermal systems (EGS) on the United States in the 21st century: an assessment. (Massachusetts Institute of Technology, 2006).

Vélez, F., Chejne, F. \& Quijano, A. "Thermodynamic analysis of R134a in an Organic Rankine Cycle for power generation from low-temperature sources". DYNA 81, 153-159 (2014).

Vetter, C., Wiemer, H.-J. \& Kuhn, D. "Comparison of sub- and supercritical Organic Rankine Cycles for power generation from low-temperature/lowenthalpy geothermal wells, considering specific net power output and efficiency". Appl. Therm. Eng. 51, 871-879 (2013).

Fecha de recepción: 13 de enero de 2021

Fecha de aceptación: 15 de junio de 2021 